ARMS-69.6.4

Distribution Category UC-41

\title{
Aerial Radiological Measuring Survey of the Indian Point Station August 1969
}

\author{
EG\&G, Inc., Las Vegas, Nevada
}

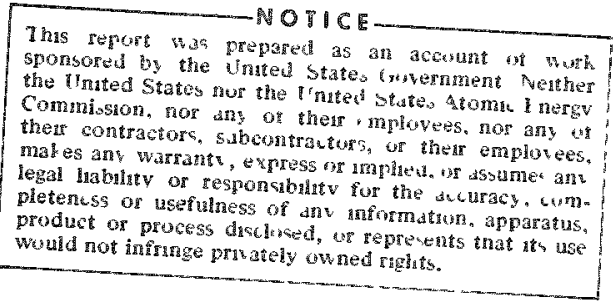

This report is part of a series on the continuing activities of the Aerial Radiological Measuring System operated for the U. S. Atomic Energy Commission. The ARMS program is managed by the Division of Opera. tional safery and is a cooperative offort among various offices and divisions of the Commission. 


\section{DISCLAIMER}

This report was prepared as an account of work sponsored by an agency of the United States Government. Neither the United States Government nor any agency Thereof, nor any of their employees, makes any warranty, express or implied, or assumes any legal liability or responsibility for the accuracy, completeness, or usefulness of any information, apparatus, product, or process disclosed, or represents that its use would not infringe privately owned rights. Reference herein to any specific commercial product, process, or service by trade name, trademark, manufacturer, or otherwise does not necessarily constitute or imply its endorsement, recommendation, or favoring by the United States Government or any agency thereof. The views and opinions of authors expressed herein do not necessarily state or reflect those of the United States Government or any agency thereof. 


\section{DISCLAIMER}

Portions of this document may be illegible in electronic image products. Images are produced from the best available original document. 


\begin{abstract}
The Aerial Radiological Measuring System (ARMS) was used to survey the area surrounding the Indian Point Station during August 1969. The survey measured terrestrial background gamma radiation and included an attempt to detect stack release gases.

A high-sensitivity detection system collected gamma-ray spectral and gross-count data. The data were then computer processed into a map of a 625 square mile area showing isoexposure contours three feet above the ground. Exposure rates and isotopes identified in the area survey are generally consistent with normal terrestrial background. A single point source of low energy photons, possibly an $x$-ray machine, was observed near the edge of the area. The plume assay revealed no radioactivity other than normal background.
\end{abstract}




\section{ACKNOWLEDGMENTS}

Special appreciation is given to L. J. Deal (Assistant Director, DOS/Health Protection, USAEC) and to Dr. Charles Pelletier (Chief, Environmental Inspection Branch, Regulatory Operations, USAEC) for their support and encouragement in this program. 
CONTENTS

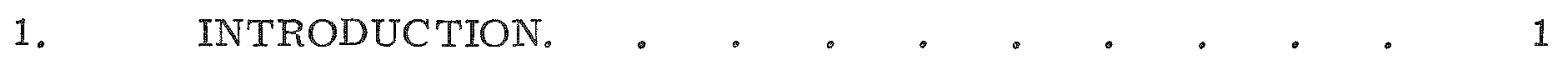

1.1 Identification of Surveyed Plant and Area . . 1

1.2 ARMS Program . . . . . . . . 1

1.3 ARMS Equipment and Procedures . . . . 1

1.4 Reduction and Presentation of Data . . . . 4

2. REACTOR AND SITE CHARACTERISTICS . . . . 5

2.1 Reactor Characteristics . . . . . . 5

2.2 Site Area Characteristics . . . . . . 6

3. SURVEY PLAN • . . . . . . . 8

3.1 Specifjcation of Flight Lines . . . . . 8

3.2 Coordination with Local Authorities. . . . . 8

4. RADIOLOGICAL SURVEY • • . . . . . . 9

4. 1 Survey Missions . . . . . . . . 9

4.2 Gross-Count Data. . . . . . . . 9

4.3 Spectral Data. . . . . . . . . 9

4. 4 Anomalous Indication . . . . . . . 11

4.5 Plume Assay..$\quad \cdot \quad \cdot \quad \cdot \quad \cdot \quad \cdot \quad \cdot \quad \cdot 11$

5. SUMMARY AND CONCLUSIONS . . . . . . 14

5.1 Area Survey . . . . . . . . . 14

5.2 Plume Assay. . . . . . . . . 14 


\section{INTRODUCTION}

\subsection{Identification of Surveyed Plant and Area}

The Aerial Radiological Measuring System (ARMS) (Ref. 1) operated by $\mathrm{EG} \& \mathrm{G}$, Inc., Las Vegas, Nevada, for the U. S. A tomic Energy Commission was used to survey an extensive area surrounding the Indian Point Station during August 1969. The Indian Point Station, operated by the Consolidated Edison Company, is located near Indian Point, New York. The size of the survey area was 625 square miles.

\subsection{ARMS Program}

The present survey was made as part of a continuing nationwide ARMS program started in 1958 to monitor radiation levels surrounding facilities producing or utilizing radioactive materials. This is the first such survey performed in the Indian Point area since the station began operation in 1962.

The detection system on board the aircraft collects gamma-ray gross-count and spectral data on each flight line of the survey. The gamma radiation and aircraft position information are processed by a computer into an isoexposure contour map of the area surveyed.

\subsection{ARIMS Equipment and Procedures}

The ARIS aircraft and its on-board radiation detection equipment were used in the survey. Since the ARMS equipment and procedures have been discussed in detail elsewhere (Ref.1), they will only be described briefly here.

The ARMS surveys are flown in a Beechcraft Twin Bonanza at an altitude of 300 to 500 feet above terrain at a ground speed of about 140 knots (235 ft/sec). The ground position of the aircraft and its altitude above terrain are measured and recorded every other second by a radar navigation computer system. The position and altitude measurements are accurate to $\pm 350 \mathrm{ft}$ and $\pm 5 \mathrm{ft}$, respectively. 
A typical flight pattern consists of a series of parallel lines spaced one nautical mile (6080 feet) apart, covering all of the land area within a twelve and one-half nautical mile radius of the facility.

At an altitude of 300 feet, the field of view of the detectors is approximately $1 / 4$ mile wide for a mean gamma energy of naturally occurring isotopes.

The aerial radiation measurements are of two distinct types, made simultaneously: (1) gross gamma count (intensity) measurements and (2) gamma spectral measurements. The detector system consists of an array of fourteen $4 \mathrm{x} 4 \mathrm{in}$. NaI (T/) scintillation crystals, each coupled to its own photomultiplier assembly. The detector system output is directed both to the gross gamma count computing system and to the multichannel spectrum analyzer. The data collecting system is shown in Figure 1.

The gross gamma count system consists of an amplifierdiscriminator-computer unit that counts and records the total number of gamma-rays of energy greater than $50 \mathrm{keV}$ that are detected during a 1 -second time interva1. The gross gamma count rate (number of gamma-rays detected per second) is digitally recorded along with aircraft position and altitude every other second. Aircraft position data are supplied by a track navigational computer and doppler radar. Altitude above terrain is measured with a radar altimeter. As a backup and complement to the digital recording of the gross-count data, a record is made on a continuous strip chart of both gross gamma count rate and radar altitude as a function of distance. Typical gross-count rates for natural background are several thousand per second.

Whereas the gross gamma count data specify the intensity of radiation as a function of position, the gamma spectral data are useful in identifying particular radioactive isotopes. A pulse-height analyzer automatically sorts detected gamma-rays according to energy, thereby generating a number per unit-energy versus energy spectrum. Although gamma rays occur only at well known discrete energies characteristic of the emitting species, air scattering tends to smear the detected distribution. Nevertheless, characteristic peaks that permit isotope identification are readily observable. In wide area surveys the typical acquisition time for a gamma-ray spectrum is several minutes; thus, the spectrum represents the average radiological properties of a tract several miles in length. However, if an area of interest is indicated by an increase in the gross gamma count rate, spectral data acquisition times of only a few seconds are used to isolate the area spatially. If further investigation is warranted, a ground mobile unit with equipment similar to that in the aircraft is available to provide greater spatial and energy resolution. 


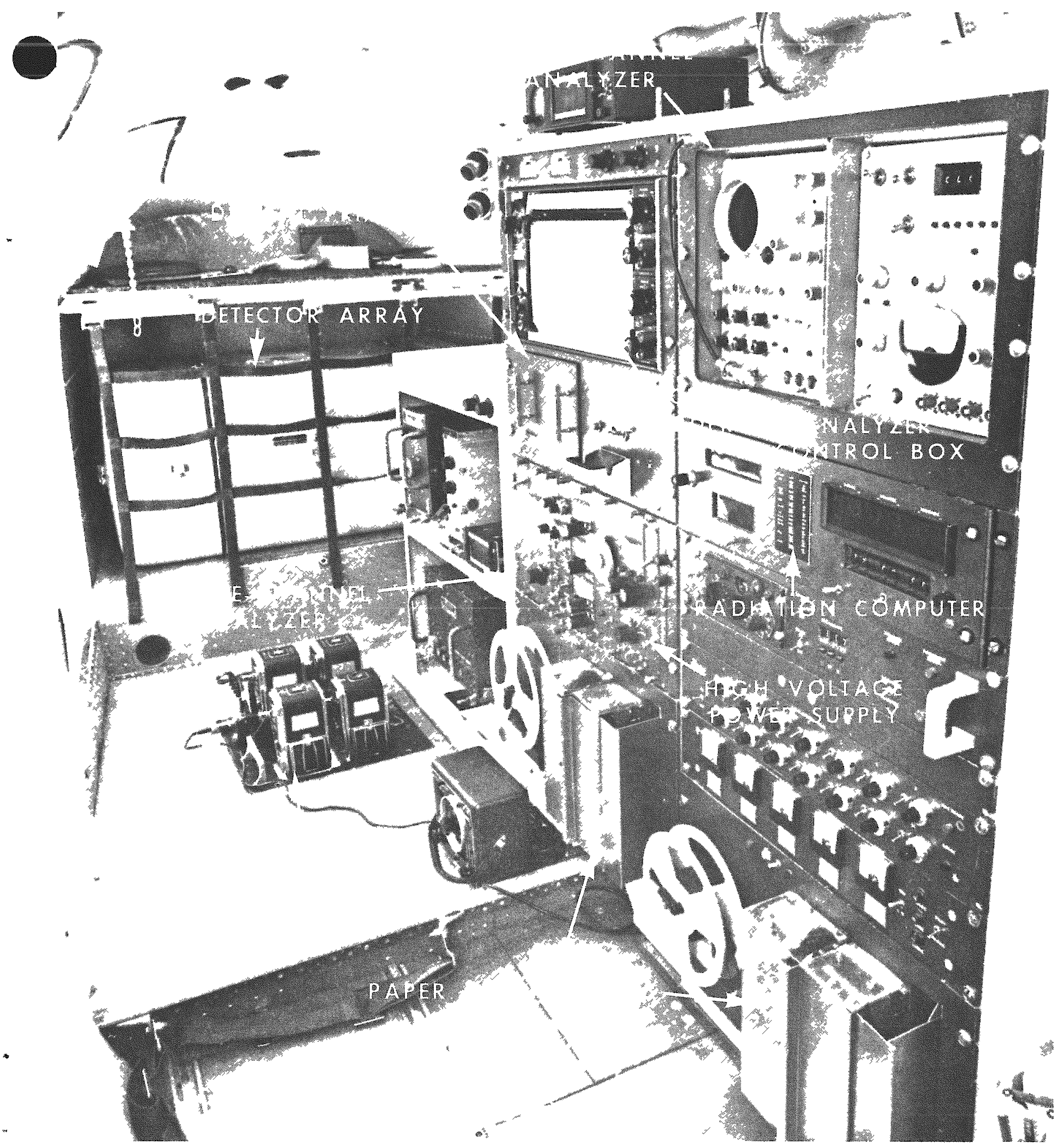

FIGURE 1. View of the interior of the Aerial Radiological Measuring System (ARMS) aircraft showing detector package and electronic data collection system. 
In addition to the equipment just described, the ARIMS aircraft also carries an air sampling and analysis system for the measurement of airborne radioactivity.

\subsection{Reduction and Presentation of Data}

The raw data from the gross gamma count and the gamma spectral measurements are permanently recorded on paper tape, which is computer processed and analyzed to characterize the radiological properties of the area surveyed. Using an altitude-dependent conversion factor obtained from prior calibration measurements, the raw gross-count rate is converted to exposure rate ( $\mathrm{R} / \mathrm{hr}$ ) at three feet above ground.

The exposure rate conversion factor was obtained from repeated flights 200 to 1000 feet above terrain containing known distributions of natural isotopes. Such conversion factors have proved valid over dis tributed fission product fields, with a variation of less than $25 \%$. In practice, variations of $2 \mathrm{uR} / \mathrm{hr}$ or greater can be reliably observed in repeated flights over the same area. 


\section{REACTOR AND SITE CHARACTERISTICS}

\section{$2.1 \quad$ Reactor Characteristics}

The Indian Point Station is located in Westchester County, New York, three miles southwest of Peekskill.

The principal nuclear contractor is the Babcock and Wilcox Company. The facility is operated by the Consolidated Edison Company of New York.

Table 1 gives the specifications of the reactor facility at the time of the survey.

TABLE 1. Reactor facility specifications.

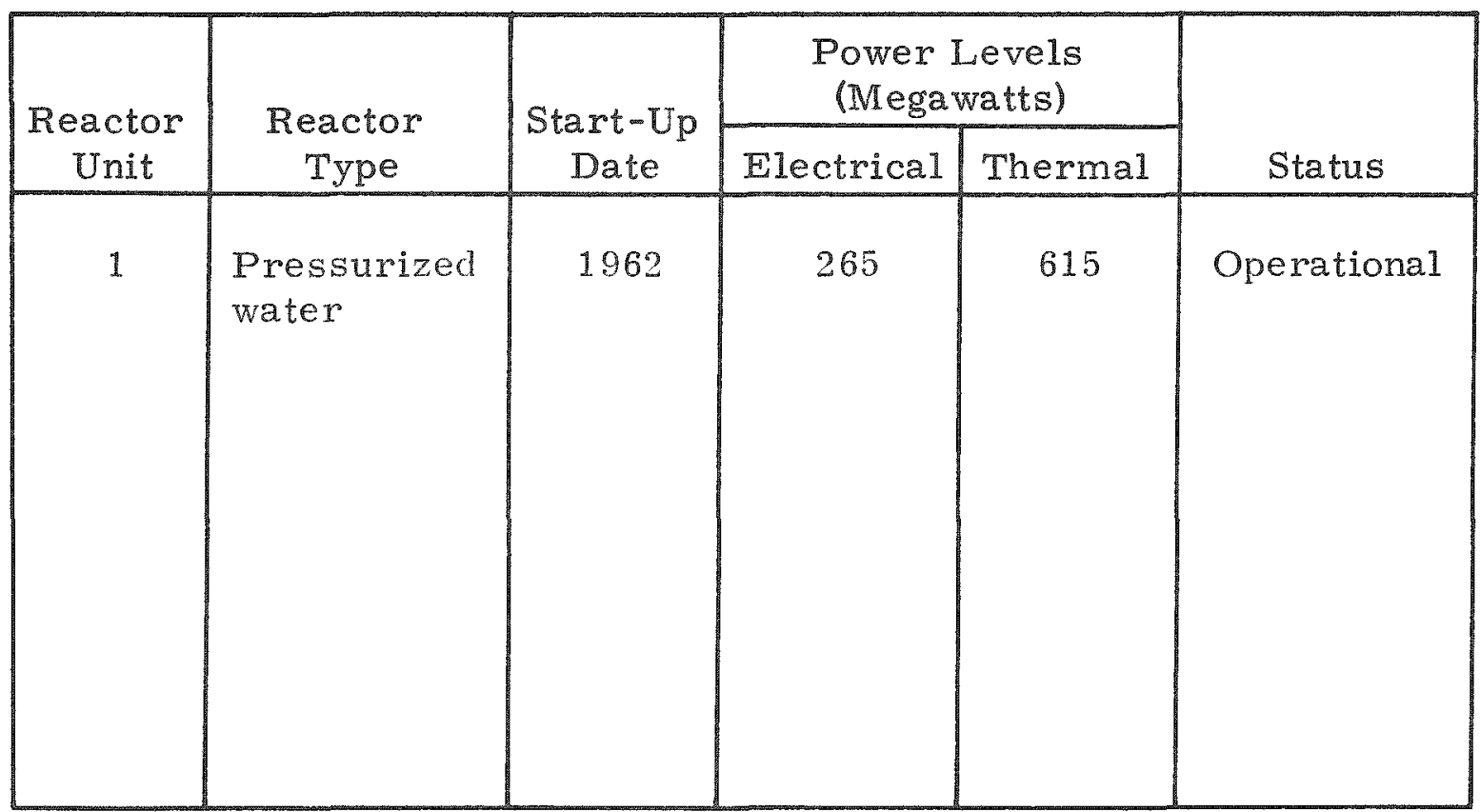




\subsection{Site Area Characteristics}

In general the terrain in the survey area consists of wooded mountains in the northern portion and rolling hills, densely populated, in the southern portion. The Hudson River runs north and south through the center of the area.

Table 2 lists the towns in the survey area with populations over 1000 , by distance and direction from the reactor site. 
TABLE 2. Principal population centers within the Indian Point area.

\begin{tabular}{|c|c|c|c|c|}
\hline \multirow[b]{2}{*}{ Town } & \multirow[b]{2}{*}{$\begin{array}{l}\text { Direction from } \\
\text { Power Station }\end{array}$} & \multicolumn{3}{|c|}{ Population * } \\
\hline & & $\frac{\text { Diste }}{0-5}$ & $\frac{m \text { Stati }}{5-10}$ & $\frac{\text { iles) }}{10-15}$ \\
\hline $\begin{array}{l}\text { Buchanan } \\
\text { Cold Springs } \\
\text { Croton on Hudson } \\
\text { Harriman } \\
\text { Haverstraw } \\
\text { Mahopac } \\
\text { Monroe } \\
\text { Montgomery } \\
\text { Mt. Kisco } \\
\text { New City } \\
\text { Nyack } \\
\text { Ossining } \\
\text { Peekskill } \\
\text { Pleasantville } \\
\text { Sloatsburg } \\
\text { Spring Valley } \\
\text { Stony Point } \\
\text { Tarrytown }\end{array}$ & $\begin{array}{l}\text { SE } \\
\mathbb{N} \\
\text { SE } \\
W \\
\text { S } \\
\text { NE } \\
\text { WNW } \\
\text { NNWW } \\
\text { E } \\
\text { S } \\
\text { S } \\
\text { SSE } \\
\text { NE } \\
\text { SE } \\
\text { SW } \\
\text { SSW } \\
\text { SW } \\
\text { SSE }\end{array}$ & $\begin{array}{l}2,110 \\
7,523 \\
8,198 \\
1,533\end{array}$ & $\begin{array}{l}27,344 \\
21,659\end{array}$ & $\begin{array}{r}2,083 \\
955 \\
5,265 \\
4,439 \\
8,172 \\
6,659 \\
\\
7,110 \\
3,134 \\
18,112 \\
11,115\end{array}$ \\
\hline Totals & & 46,515 & 49,003 & 62,605 \\
\hline Grand Total & & & & 158,123 \\
\hline
\end{tabular}

* 1970 Census figures (Ref.2). 


\section{SURVEY PLAN}

\subsection{Specification of Flight Lines}

The flight pattern for the Indian Point survey consisted of 25 flight lines approximately 25 nautical miles long and spaced one nautical mile apart. The flight lines were oriented in a north-south direction. Radiation data together with aircraft position and meteorological information were collected along each flight line.

\subsection{Coordination with Local Authorities}

ARMS survey missions are conducted under special waiver from the Federal Aviation Administration. The survey plan was discussed with the appropriate General Aviation District Office, and public announcements were published in the local newspapers prior to the survey operation in accordance with the FAA waiver for low-level flights.

The base of operations for the survey mission was West Springfield, Massachusetts. 


\section{RADIOLOGICAL SURVEY}

\subsection{Survey Missions}

The aerial survey of the Indian Point Station area was conducted on 18, 20, and 21 August 1969. This survey required a total flying time of 15. 1 hours. A plume assaymission was flown on 21 August 1969.

Gross-count and spectral data were simultaneously collected at an altitude of 300 feet. Spectral collections were accumulated over a four minute interval during which the aircraft traveled approximately 12 miles; consequently, two spectra per line were collected.

\subsection{Gross-Count Data}

As a first step in the analysis of the gross-count data, the background due to nonterrestrial radiation was subtracted. This background consists of cosmic-ray, aircraft, and airborne radioactivity contributions (Ref. 3). After correction for background, the data were normalized to a standard air mass. The resultant net-count data were then converted to exposure rate in microroentgens per hour ( $\mathrm{R} / \mathrm{hr}$ ) at the 3 -foot level above the ground. The cosmic-ray exposure rate was then added back to the terrestrial exposure rate. Finally, the composite exposure rate data, together with aircraft position information, were processed into an isoexposure contour map for overlay on U. S. Geological Survey topographic maps of the survey area.

An isoexposure map of the Indian Point area is shown in Figure 2. Exposure rates for the northwest half of the survey area. are not shown; because of the rough terrain in this region, the grosscount data are unreliable. The data shown on the map include a cosmic radiation contribution of 2 to $4 \mathrm{uP} / \mathrm{hr}$. Spatial resolution of the exposure rate data is determined by the field of view of the detector system, which is about $1 / 4$ mile. Except for a single anomalous point discussed below (Section 4.4), exposure rates are consistent with normal terrestrial background.

\subsection{Spectral Data}

Spectral data were recorded from about 0.03 to $3.0 \mathrm{MeV}$. The recording system was calibrated prior to takeoff with an yttrium-88 source, 


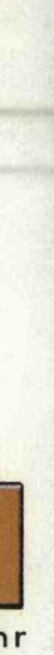$$
\text { . }
$$

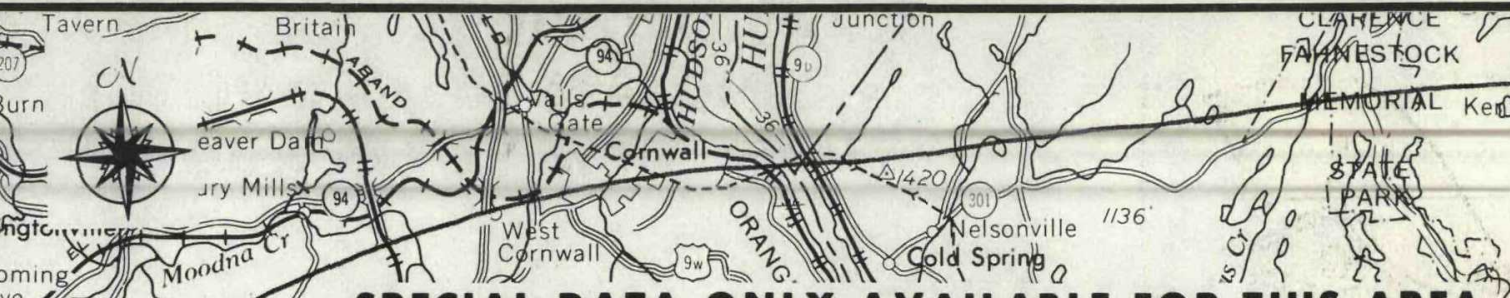

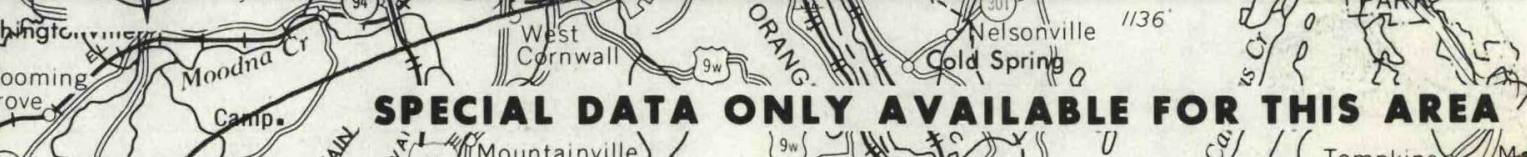

$10-12 \mu R / h$

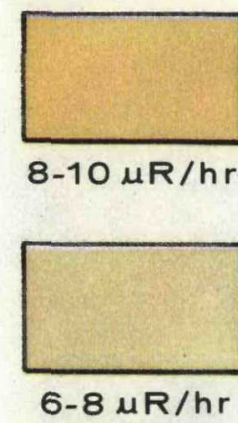

$6-8 \mu R / h r$
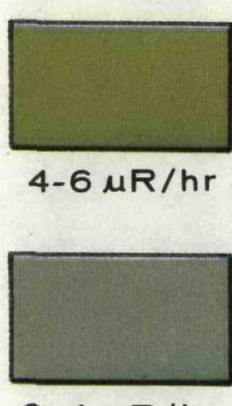

$2-4 \mu R / h r$

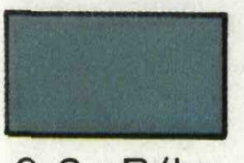

$0-2 \mu R / h r$

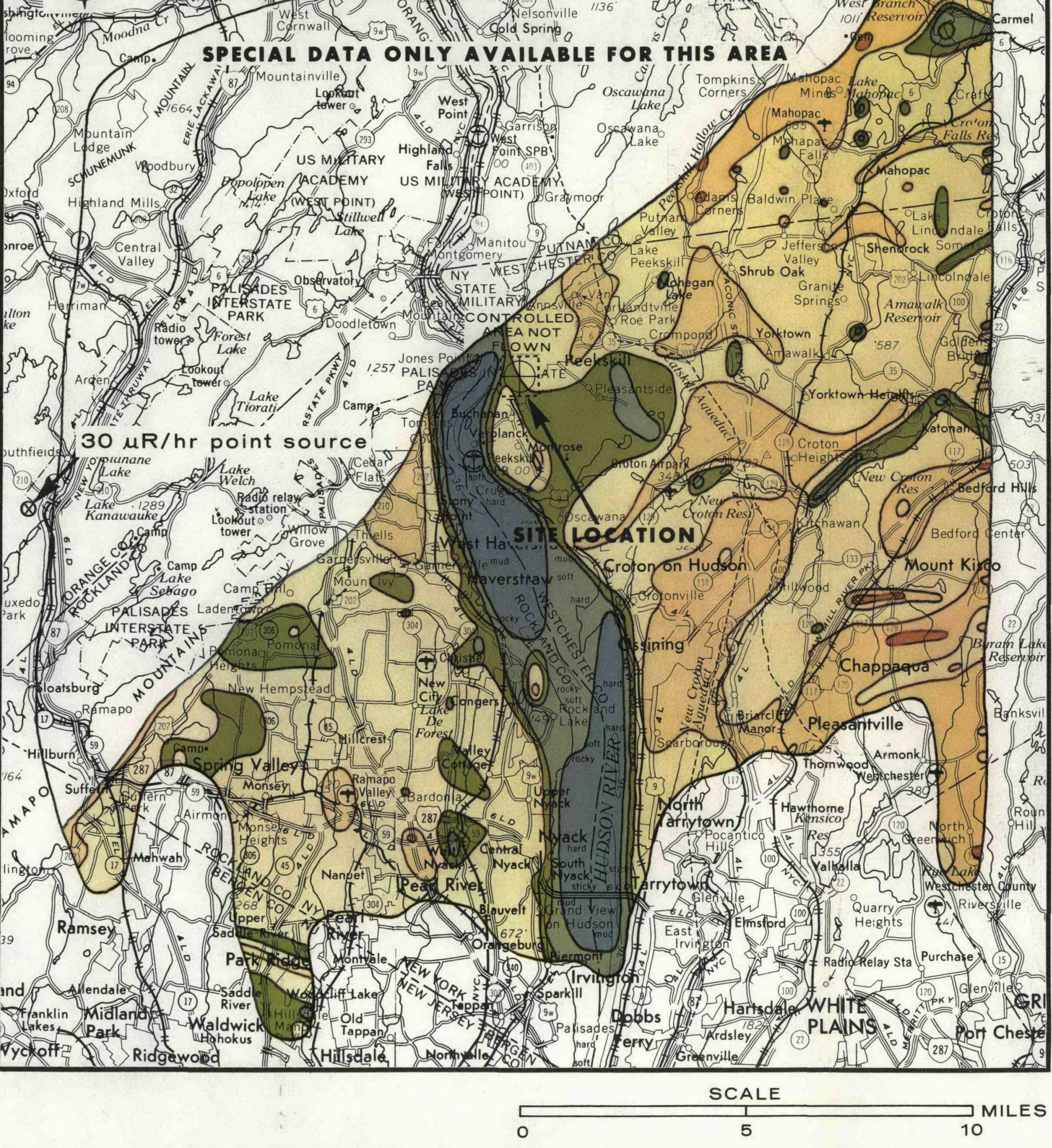

GAMMA RAY ISOEXPOSURE RATE CONTOURS
RADIOLOGICAL SURVEY DATA FOR THE INDIAN POINT POWER PLANT NEW YORK, AUGUST 1969

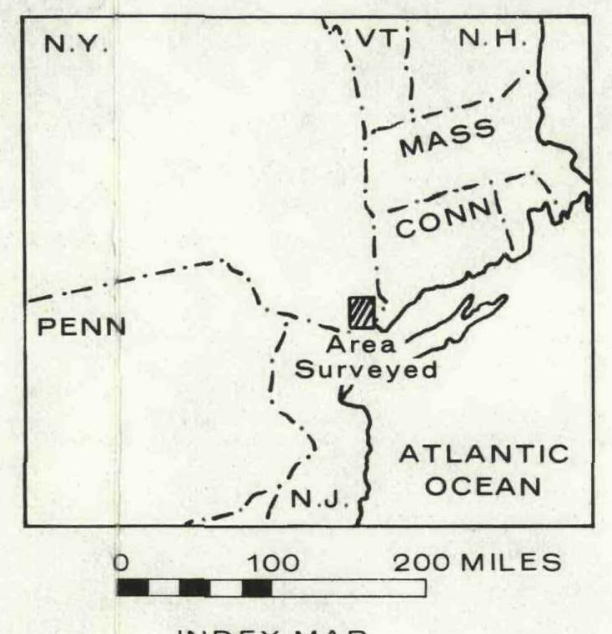

NDEX MAP

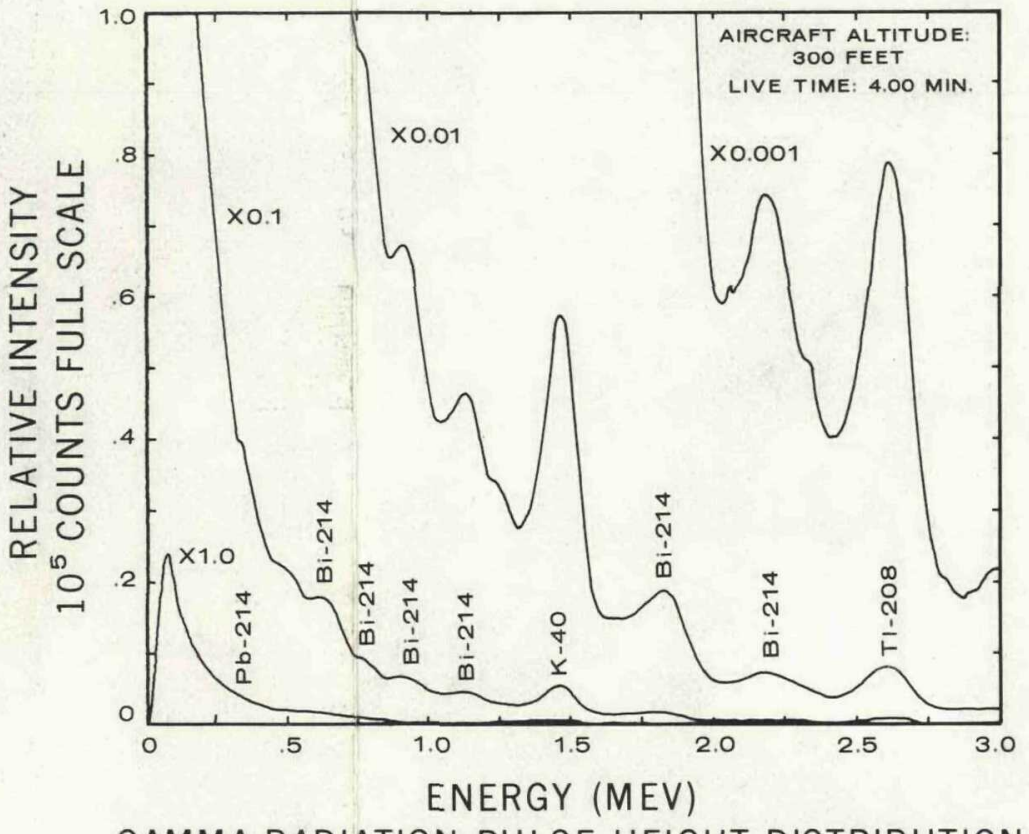

GAMMA RADIATION PULSE HEIGHT DISTRIBUTION

(EXPOSURE RATE DETERMINED BY INTEGRATING THE GAMMA RAY SPECTRUM BETWEEN $50 \mathrm{keV}$ AND $6 \mathrm{MeV}$ THE ISOEXPOSURE RATE CONTOUR INTERVALS SHOWN ARE IN $\mu R / h r$ AT THE 3-FOOT LEVEL AND INCLUDE TERRESTRIAL AND COSMIC RAY CONTRIBUTIONS

FIGURE 2 
which enuils lwo prominenl gannua-rays of 0.898 and $1.836 \mathrm{MeV}$. The gain for each crystal in the 11-crystal detcctor array was set independently.

A spectrum typical of those taken in the survey area is shown in Figure 3. Table 3 lists the prominent gamma-ray energies and associated source isotopes identified in the spectrum. Differences in shape between spectra taken over different portions of the survey area are minor, and the isotopes identified in all spectra are the same. Only isotopes consistent with normal background radiation are apparent.

\section{4. $4 \quad$ Anomalous Indication}

An abnormally high exposure rate of $30 \mathrm{UR} / \mathrm{hr}$ was observed 1.5 miles west of Southfield, New York, on the western edge of the survey area. The source was apparently a single point, located in an industrial complex. Additional spectral data accumulated over the anomalous point indicate that the increased exposure rate was due to a low energy photon source, possibly an $x$-ray machine.

\subsection{Plume Assay}

An attempt to detect an effluent plume at the Indian Point Station was made on 21 August 1969. At that time the nominal stack release rate (provided by the plant opcrator) was zero. Several passes at various altitudes were made; however, no radiation above background levels could be discerned with the crvstal detectors. Results from air filter measurements were likewise nogative. 


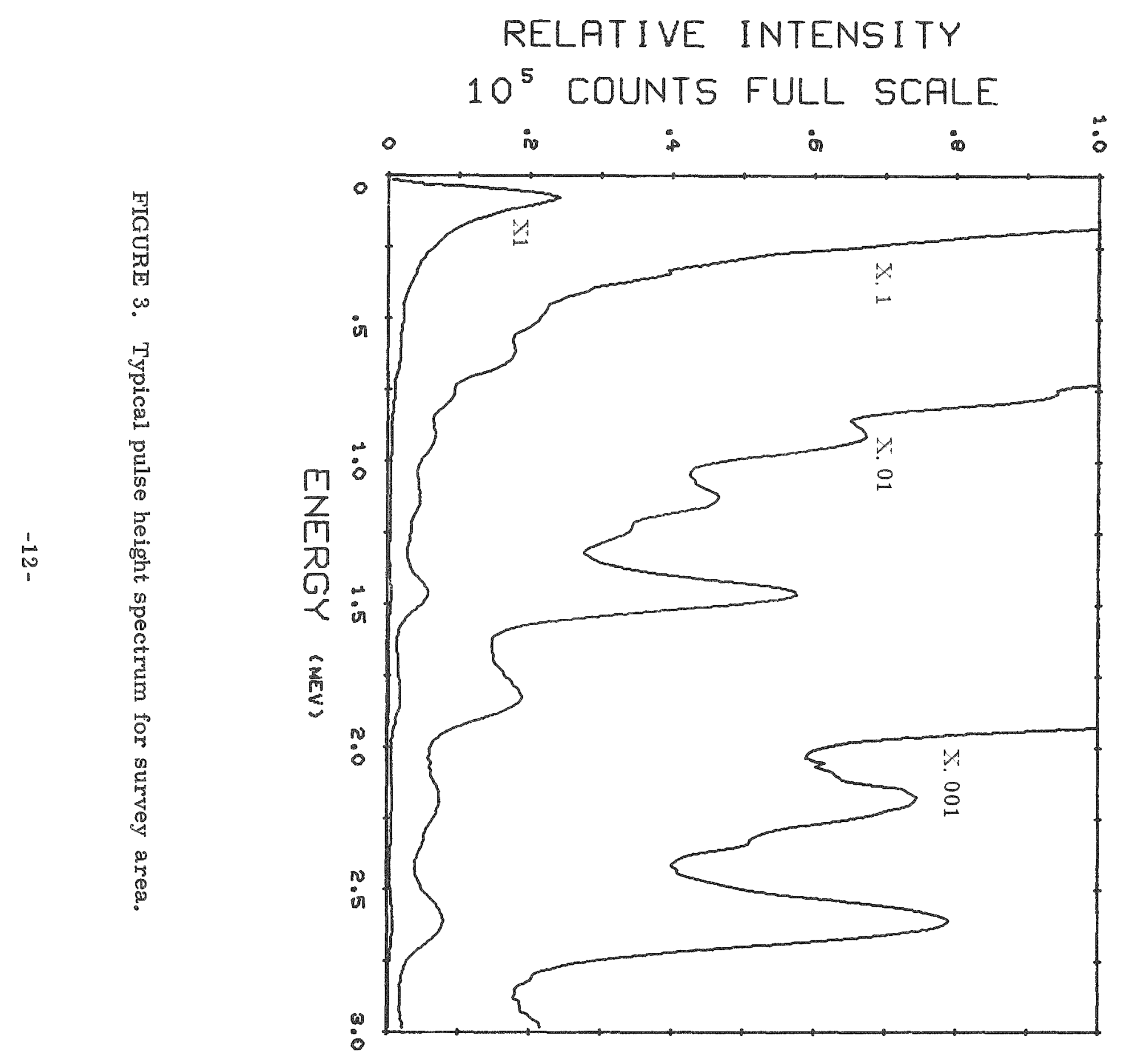


TABIE 3. Gamma-ray energies and isotopes consistent with spectral data of Figure 3 .

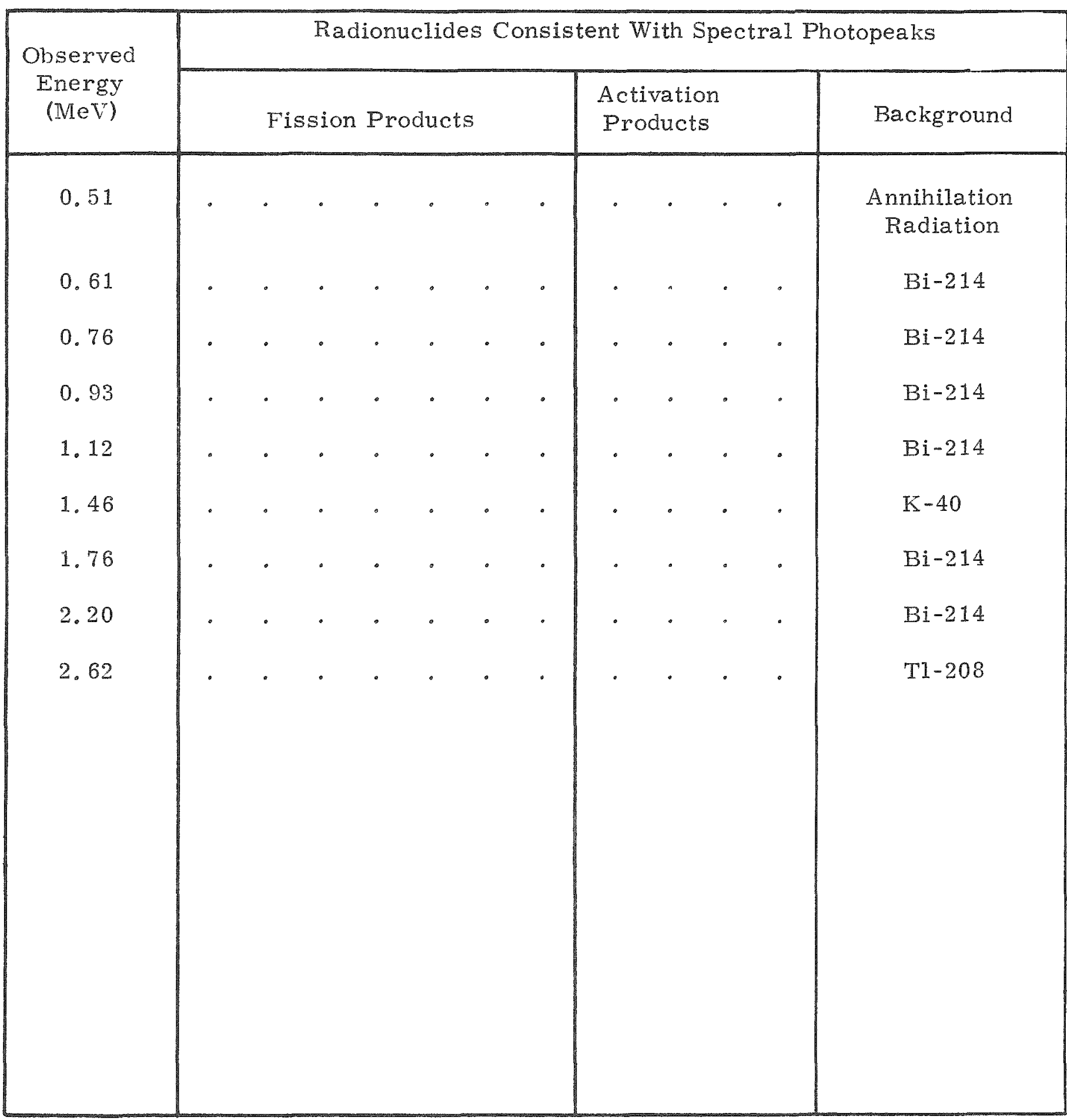




\section{SUMMARY AND CONCLUSIONS}

\subsection{Area Survey}

Except for the single anomalous low energy photon source discussed in Section 4.4 , the exposure rates and radioactive isotopes revealed in the survey of the area surrounding the Indian Point Station are consistent with normal terrestrial background radiation. No anomalies were detected that could be attributed to reactor operations.

The 3-foot level exposure rates mapped during the survey are mostly in the 2 to $10 \mathrm{uR} / \mathrm{hr}$ range.

\section{$5.2 \quad$ Plume Assay}

The plume assaydata revealed only terrestrial background radiation levels and isotopes. 


\section{REFERENCES}

1. "Aeria1 Radiological Measuring Systems (ARMS) - Systems and Procedures Iimployed Through FY71," AEC Report No. ARMS-71.6, in preparation.

2. 1970 Census of Population, Advance Report PC(VI)-3Y, U. S. Dept. of Commerce, Bureau of Census, January 1971.

3. Burson, Z. G., Boyns, P. K., and Fritzsche, A. E., "Technical Procedures for Characterizing the Terrestrial Gamma Radiation Environment by Aerial Surveys, "EG\&G/LVAO Report No. $1183-1559,1972$. 